\title{
Human capital depreciation during family-related career interruptions in male and female occupations
}

Citation for published version (APA):

Görlich, D., \& de Grip, A. (2007). Human capital depreciation during family-related career interruptions in male and female occupations. Researchcentrum voor Onderwijs en Arbeidsmarkt, Faculteit der Economische Wetenschappen. ROA Research Memoranda No. 7 https://doi.org/10.26481/umaror.2007007

Document status and date:

Published: 01/01/2007

DOI:

10.26481/umaror.2007007

Document Version:

Publisher's PDF, also known as Version of record

\section{Please check the document version of this publication:}

- A submitted manuscript is the version of the article upon submission and before peer-review. There can be important differences between the submitted version and the official published version of record.

People interested in the research are advised to contact the author for the final version of the publication, or visit the DOI to the publisher's website.

- The final author version and the galley proof are versions of the publication after peer review.

- The final published version features the final layout of the paper including the volume, issue and page numbers.

Link to publication

\footnotetext{
General rights rights.

- You may freely distribute the URL identifying the publication in the public portal. please follow below link for the End User Agreement:

www.umlib.nl/taverne-license

Take down policy

If you believe that this document breaches copyright please contact us at:

repository@maastrichtuniversity.nl

providing details and we will investigate your claim.
}

Copyright and moral rights for the publications made accessible in the public portal are retained by the authors and/or other copyright owners and it is a condition of accessing publications that users recognise and abide by the legal requirements associated with these

- Users may download and print one copy of any publication from the public portal for the purpose of private study or research.

- You may not further distribute the material or use it for any profit-making activity or commercial gain

If the publication is distributed under the terms of Article $25 \mathrm{fa}$ of the Dutch Copyright Act, indicated by the "Taverne" license above, 


\section{Human Capital Depreciation during Family- related Career Interruptions in Male and Female Occupations}

Dennis Görlich

Andries de Grip

ROA-RM-2007/7

Month 10

Research Centre for Education

and the Labour Market

P.O. Box 616

6200 MD Maastricht

The Netherlands

E-mail: $\quad$ mailto:secretary@roa.unimaas.nl

Internet: $\quad$ http://www.roa.unimaas.nl

Maastricht University

Faculty of Economics and Business Administration 
The ROA Research Memorandum Series was created in order to make research results available for discussion, before those results are submitted for publication in journals. 
ROA-RM-2007/7 » http://www.roa.unimaas.nl/resmem.htm

\section{Abstract}

\section{Human Capital Depreciation during Family-related Career Inter- ruptions in Male and Female Occupations ${ }^{1}$}

This study investigates the relation between human capital depreciation during family-related career interruptions and occupational choice of women in the (West) German labour market. In contrast to other studies that do not explicitly focus on family-related career interruptions, we find that short-term human capital depreciation during these career interruptions is significantly lower in female occupations than in male occupations. This holds for both high- and low-skilled occupations. Our findings support the self-selection hypothesis with respect to occupational sex segregation, i.e. women might deliberately choose female occupations because of lower short-term wage penalties for familyrelated career interruptions. Moreover, we find that particularly men employed in high-skilled male occupations face large short-run as well as long run wage penalties when they have a family related career break.

JEL Codes: J16; J22, J24

Keywords: Occupational segregation, career interruptions, human capital depreciation

Dennis Görlich

The Kiel Institute for the World

Economy

Düsternbrooker Weg 120

24105 Kiel (Germany)

dennis.goerlich@ifw-kiel.de
Andries de Grip

ROA

P.O. Box 616

6200 MD Maastricht

a.degrip@roa.unimaas.nl

1. The authors thank Miriam Beblo, Ben Kriechel, Anna Matysiak, and Jasper van Loo for their comments on earlier versions of this paper. 



\section{Introduction}

In the past decades, many studies analysed the occupational segregation between male and female workers (cf. Beller, 1982; Karmel \& Maclachlan, 1988; Boisso, 1994). Although occupational segregation by gender could reflect efficiency reasons (Jacobsen, 1998) and individual preferences (cf. Bender, Donohue, \& Heywood, 2005), it is also responsible for a large part of the gender wage gap because women are overrepresented in lower paying occupations (cf. Fain, 1998; Reed \& Dahlquist, 1994; Jurajda \& Harmgart, 2003). Moreover, there are fewer career opportunities in female occupations than in male occupations (Jacobsen, 1998). For these latter reasons, it is often argued that occupational segregation is a result of discrimination of female workers.

However, occupational segregation by gender may also be caused by selfselection. Bender et al. (2005) found that job satisfaction of women is higher in workplaces dominated by female workers. The relevance of self-selection is supported by Borghans \& Groot (1999) who found that educational segregation is a major cause of occupational segregation by gender. It is in-teresting to see that public policies particularly attempt to tackle occupational sex segregation by affecting educational pre-sorting. A prominent example in many countries is the effort taken to encourage interest in technical studies among girls. Such policies implicitly assume that women choose female occupations due to a lack of information about male occupations.

Yet, self-selection of workers may occur for a variety reasons. Some studies found that women self-select into female occupations because these occupations offer more pleasant working conditions, flexibility (Bender et al., 2005; Filer, 1985), and more family-friendly human resource policies (Datta Gupta \& Smith, 2000; Skyt Nielsen et al., 2004). ${ }^{2}$ However, other studies did not find any evidence for self-selection motivated by such considerations on

2. These arguments refer to the traditional theory of compensating wages, since it seems that women trade in a part of their wage for more amenities, which are not enjoyed in male occupations. Consequently, female occupations feature a lower pay level according to this theory. 
compensating wages, despite significant differences in working conditions (Reed \& Dahlquist, 1994; Trappe and Rosenfeld, 2004). ${ }^{3}$

Yet, there may be a major financial reason for self-selection: if women plan to eventually interrupt their career for family reasons (e.g. pregnancy, child rearing, household tasks), they may optimise life-time earnings by choosing to work in female occupations because of lower wage "penalties" for career interruptions. In other words, the wage decrease resulting from human capital depreciation during a possible career interruption for family reasons may be lower in female occupation than in male occupations (cf. Polachek, 1981) McDowell (1982) found support for this self-selection argument, by analyzing the durability of knowledge in different disciplines. He found that women who pursue an academic career are more often employed in disciplines like humanities where knowledge depreciates more slowly during a career interruption.

In this paper, we will analyze whether human capital depreciation during family-related career interruptions is lower in female occupations than in male occupations on the German labour market. If this is the case, it indicates that occupation-specific depreciation rates during family-related career breaks may affect occupational sex segregation by self-selection. The depreciation rates of six different occupational groups will be estimated by means of a fixed-effects model using the four panel waves 1998-2001 from the German Socio-Economic Panel (GSOEP). These six occupational groups distinguish between male, integrated, and female occupations with high and low skill requirements, respectively.

Our study contributes to the literature in several ways. First, unlike other studies (e.g. England, 1982; Kunze, 2002; Mincer \& Polachek, 1978; Polachek, 1981), we focus on the effects of human capital deprecation during family-related career interruptions. We do this because only interruptions due to family

3. Also Lewis and Shorten (1991), Fain (1998), and Hansen and Wahlberg (2000) found support for the self-selection theory, using Australian, U.S., and Swedish data, respectively. .However, these studies do not distinguish between financial and other determinants. 
reasons can influence a person's occupational choice ex ante, as these interruptions are the only type of interruptions that can be anticipated to a large extent. Moreover, family-related career interruptions are currently the main difference in male and female patterns of labour market participation (Datta Gupta \& Smith, 2002).

Second, we analyse depreciation rates of both men and women, while others concentrate either on women only (for instance Beblo \& Wolf, 2000), or do not analyse human capital depreciation during family-related career interruptions for men (Kunze, 2002). The latter is particularly interesting because in the German labour market men have a low but sizeable amount of family-related career interruptions. This enables us to analyze whether men and women face different human capital depreciation rates in male or in female dominated occupations.

Third, we analyse whether human capital depreciation rates differ between high and low skilled occupations, whereas other studies either focus on only one skill level (Kunze, 2002), or on human capital depreciation rates related to the worker's level of education, instead of the skill level of the occupation (Mincer \& Polachek, 1974). Distinguishing between low-skilled and high-skilled occupations is more sensible in our context as the individual level of education is not necessarily connected to occupational choice (see e.g. Groot \& Maassen van den Brink, 2000).

Fourth, opposite to other studies (England, 1982; Polachek, 1981), we distinguish between short- and long-run human capital depreciation effects of career interruptions, as both effects might influence the decision to interrupt the career differently.

Our main finding is that, in the short run, human capital depreciation during family-related career interruptions is significantly lower in female occupations than in male occupations. This holds especially for both high-and low-skilled occupations in the overall and female sample. Our results are consistent with Polachek's (1981) hypothesis that occupational sex segregation is the result of women's self-selection into female occupations on the basis of anticipated human capital depreciation rates. Moreover, we find that short-term 
depreciation rates after a career break for family reasons are smaller than after unemployment or career breaks for other reasons. However, particularly men who are employed in a high-skilled male occupation face large short-run wage penalties as well as an enduring wage penalty when they have a family-related career break, which may indicate that these men are stigmatised as being less motivated and less career-oriented.

\section{Prior Research}

The skills of workers with career interruptions may depreciate because they may not be using or updating them during the interruption. More precisely, they may be subject to technical as well as economic obsolescence of their human capital: they may face atrophy (loss of skill due to limited or non-use), skills obsolescence due to technological and organisational developments (loss in the value of a worker's skill due to non-updating), and firm-specific human capital obsolescence (loss in the value of the worker's skill due to firm change) (De Grip \& Van Loo, 2002).

A common way to measure the actual rate of this human capital depreciation is to extend Mincer's (1974) earnings function, so that it can account for heterogeneous employment histories of workers, and therefore incorporates information on possible career interruptions (see for example Mincer \& Polachek, 1974; Polachek, 1981; Light \& Ureta, 1995; Beblo \& Wolf, 2003).

In its simplest form, the earnings equation allowing for human capital depreciation looks as follows (Mincer \& Polachek, 1974):

$$
\ln E_{t}=\ln E_{0}+\sum_{i=0}^{t-1}\left(r k_{i}-\delta_{i}\right)
$$

where $E_{t}$ is a person's earnings potential at time $t, E_{0}$ is initial earnings potential, $r$ is the rate of return to human capital investment, $k_{i}$ is the gross human capital investment ratio in period $i$ (i.e. human capital investment divided by earnings in period $i$ ), and $\delta_{i}$ measures the depreciation rate. Note that $\delta$ might vary over $i$, i.e. it might be different at different points in time.

In order to make equation (1) estimable, Mincer and Ofek (1974) include periods of career interruptions: 


$$
\ln E_{t}=\ln E_{0}+\left(r s-\delta_{s}\right)+\left(r k_{1}-\delta_{1}\right) e_{1}+\left(r k_{h}-\delta_{h}\right) h+\left(r k_{2}-\delta_{2}\right) e_{2}
$$

where $r_{s}$ is return to schooling and $\delta_{s}$ is the depreciation rate of the schooling, $e_{1}$ is the duration of the working spell before the interruption, $h$ is the duration of the career interruption, and $e_{2}$ is the working spell after the interruption. If it is assumed that human capital investment $k_{h}$ is zero during home time $h$, the regression coefficient of $h$ (i.e. $r k_{\mathrm{h}}-\delta_{h}$ ) is an estimator of the human capital depreciation rate.

As expected, Mincer and Polachek (1978) found that the coefficient for home time is negative for women on the U.S. labour market, which indicates the depreciation of their human capital. ${ }^{4}$ Furthermore, their results show that depreciation rates are much higher for higher educated women than for uneducated women, for whom the coefficient is statistically insignificant. Finally, Mincer and Polachek found that atrophy varies by level of education: for high-skilled workers career interruptions are most costly. ${ }^{5}$

According to Mincer and Ofek (1982), human capital depreciation rates can be different depending on the point in time when these rates are measured, i.e. there are short-term and long-term depreciation rates. In their study, they distinguish four phases in a worker's career: (1) the working spell before the interruption, (2) the non-working spell, (3) the so-called restoration period, and (4) the post-restoration period. Directly after a career interruption, the wage of the worker is considerably lower than before. Moreover, post-interruption wages are lower the longer is the interruption. However, wages increase rapidly during the restoration period, because during this phase previously eroded human capital is restored and such a process is quicker and less costly than building up completely new human capital. Eventually, wage growth slows down and continues to grow at a rate similar to that of a worker who does not interrupt his career.

4. After criticism by Sandell and Shapiro (1978), Mincer and Polachek (1978) repeated their 1974study with a different and newer data set, so that we report the 1978 results here.

5. Note that Mincer and Polachek $(1974,1978)$ did not account for unobserved heterogeneity and endogeneity (Kim \& Polachek, 1994). 
Mincer and Ofek (1982) distinguished between two career interruptions at two different points in time. Their model looks as follows:

$$
\ln w_{T}=\alpha s+\beta e_{0}+\delta_{2} h_{0}+\delta_{1} h_{1}+\mu x_{T},
$$

where $e_{0}$ represents the duration of past labour force participation, and $h_{0}$ and $h_{1}$ denote the duration of past and recent spells of career interruption, respectively. Note that, considering the sequence of events, $h_{0}$ is the first spell in this setup, followed by $e_{0}$, then followed by $h_{1}$, which is the interruption just completed at time $T$. This specification enables Mincer and Ofek to determine the long- and short-run effect of a career interruption, since home time spell $h_{0}$ lies longer in the past than home time spell $h_{1}$. When the equation is estimated at time $T$, the coefficient $\beta$ measures the long-run effect of experience, and $\delta_{2}$ and $\delta_{1}$ are the long- and short-run depreciation rates during non-participation spells, respectively. ${ }^{6}$ The variables $s$ and $x$ represent schooling, and variables such as tenure, dummies for layoff, unemployment, marriage, or children, respectively. The empirical results of Mincer and Ofek support their hypothesis that there is a restoration period, as depreciation rates appear to be higher in the short run than in the long run.

Light and Ureta (1995) refined the studies of Mincer and Ofek (1974, 1978). Their work history model includes experience variables that measure "the fraction of time worked and not worked in the last year, 2 years ago, 3 years ago, and so forth, back to the beginning of the career" (p. 129-30). The work history model proves to be superior to the traditional models, which only use one variable for either potential or actual experience. ${ }^{7}$ The estimation results of Light and Ureta show that early-career wage growth estimates are downward biased in the standard models, because negative wage effects of career interruptions are included in the estimates.

Obviously, career interruptions do not only take place due to family reasons, but also due to unemployment, sick leave, or other events. Different types of career interruptions may lead to different magnitudes of the wage effect, because there

6. Provided that there is no human capital investment during the non-working spell.

7. Potential experience is calculated as workers' age minus the duration of their schooling minus 6 . Actual experience is the cumulative sum of years in employment. 
might be a signalling or stigma effect connected to certain types of interruptions. For example, a period of parental leave might convey a more positive signal to a potential employer than a period of unemployment. Moreover, the effect of the former might differ between men and women. Albrecht et al. (1999) found a negative stigma effect after parental leave for Swedish men, while parental leave has no effect on women's wages. ${ }^{8}$ In a similar study for Germany, Beblo and Wolf (2002; 2003) extended the work history model with different types of career breaks. They found that parental leave has a stronger negative effect on women's wages than other types of interruptions. ${ }^{9}$ Note, that their findings on the effects of parental leave for women stand in stark contrast to the results of Albrecht et al. (1999) in Sweden, although the models used in the two studies are similar. This indicates that the wage effects of career interruption may be highly sensitive to different national labour market institutions or cultural values.

Polachek (1981) suggested a direct link between human capital depreciation rates and occupational choice. He argued that women, who expect to interrupt their careers in order to take care of the family, will choose occupations where the penalty for their absence due to human capital depreciation is lowest, as this will maximise their lifetime income. If female occupations feature the lowest human capital depreciation rates, and women indeed sort themselves into these jobs, human capital depreciation rates could be part of the explanation for occupational sex segregation. Polachek (1981) indeed found that human capital depreciation rates are highest in professional and managerial occupations, which are predominantly male occupational groups, while human capital of workers doing e.g. household work (a female dominated occupation) hardly depreciates at all. ${ }^{10}$

8. They included parental leave, household time, other time out, unemployment, and military leave. Interruptions other than parental leave affected both men's and women's wages negatively.

9. They were not able to estimate the effect of parental leave on men's wages, because too few men had been on parental leave.

10. Although Polachek (1981) refers to the atrophy rate, his estimate of human capital depreciation might also measure skills obsolescence due to technological change. 
A major problem with Polachek's conclusions is that he does not directly test the influence of depreciation rates on occupational sex segregation, because his choice of occupational groups does not reflect the extent of segregation in these groups. England (1982) corrected for this by constructing occupational groups according to the degree of "femaleness". However, she did not find any evidence for occupational self-selection motivated by lower depreciation rates. ${ }^{11}$ Moreover, England showed that not only women with career interruptions work in female occupations, but also those in continuous employment. Accordingly, she argued that human capital theory fails to account for occupational segregation, so that she proposed discrimination as the culprit. Kunze (2002) conducted a similar study for "young skilled workers" in Germany and did not find support for Polachek's theory, either. In contrast to England, she analysed depreciation rates for different types of interruptions and found that women on parental leave experience lower depreciation rates in male and integrated occupations. Consequently, she concluded that occupational sex segregation does not result from self-selection motivated by lower depreciation rates. However, Kunze only focuses on the registered maternity and parental leave ${ }^{12}$ of young women who participated in apprenticeship training.

\section{Hypotheses}

This study examines the role that family-related career interruptions can play in occupational sex segregation. For this purpose, we test whether human capital depreciation rates during family-related career interruptions are lower in female occupations than in male occupations, which might be a motivation for women who expect to interrupt their career for family reasons to deliberately select female occupations. Opposite to the above-mentioned studies by Polachek (1981), and England (1982), we explicitly focus on the wage effects of familyrelated career interruptions. We limit our focus on family-related interruptions because, unlike other types of career interruptions, family-related interruptions

11. Remarkably, England found significantly higher human capital depreciation rates in occupations with a high fraction of females.

12. The registered data used by Kunze also include long-term sick leave. 
are voluntary and can be anticipated. ${ }^{13}$ Moreover, family-related career interruptions often take place rather early in a worker's career. This early stage might imply that women are more able to take it into account at the time of their occupational choice (cf. Beblo \& Wolf, 2000).

Furthermore, German legislation offers a system with long potential formal parental leave. ${ }^{14}$ This gives family-related career interruptions a special importance on the German labour market, for both men and women, and might therefore have a significant influence on occupational choice.

Moreover, the wage effects of formal parental leave are probably different from the effects of other types of career interruptions, because special costs and benefits are connected to it. On the benefit side, parental leave policies encourage continued labour force attachment of women and retain specific human capital for the firm (Hashimoto, Percy, Schoellner, \& Weinberg, 2004; Ondrich et al., 2002). On the cost side, such policies decrease labour market flexibility, and raise labour costs, because a firm might need to hire and train temporary workers to replace women who are on parental leave. These costs might be passed on to the returning mother in form of lower wages (Ondrich et al., 2002).

We follow Kunze (2002) in defining occupational groups according to the percentage of women employed in it. We distinguish three categories of occupations: male occupations, integrated occupations, and female occupations.. Since skill level requirements of an occupation can influence the size of the depreciation rate as well (Mincer and Polachek,1978; Neuman and Weiss, 1995), we also distinguish between high- and low-skilled occupations. This leaves us with six occupational groups: male, integrated, and female

13. A career interruption due to unemployment can also be voluntary, but we assume here that unemployment is often involuntary. Another voluntary type of career interruptions are sabbaticals, but sabbaticals hardly occur in our sample.

14. While maternity leave in the U.S. only spans over 12 weeks (Hashimoto et al., 2004), it varies from 12 weeks to 3 years in European countries (Ruhm, 1996). In Germany, parents (thus both mothers and fathers) are entitled to parental leave until the third birthday of their child with full guarantee to return to their old workplace (Ondrich et al., 2002). 
occupations with high skill requirements, and male, integrated, and female occupations with low skill requirements.

If women self-select into female occupations on basis of lower depreciation rates, we expect significantly lower depreciation rates in female occupations, as compared to male occupations. A validation of the following two hypotheses would thus be support for the theory of self-selection on basis of deprecation rates (Polachek, 1981).

\section{Hypothesis 1:}

The depreciation rate of human capital in high-skilled male occupations is larger than the depreciation rate in high-skilled female occupations:

$$
\delta_{H, \text { male }}>\delta_{\mathrm{H}, \text { fem}} \text {. }
$$

Hypothesis 2:

The depreciation rate of human capital in low-skilled male occupations is larger than the depreciation rate in low-skilled female occupations:

$$
\delta_{L, \text { male }}>\delta_{L, \text { fem. }}
$$

We will test these hypotheses for both short- and long-run depreciation rates, because it is not clear a priori, which of the two is taken into account for occupational choice.

\section{Data}

For our analysis, we use data from the German Socio-Economic Panel (GSOEP). GSOEP offers detailed data on a person's employment history distinguishing between full-time employment, part-time employment, unemployment spells, and spells during which one was off the labour market due to family reasons. We will use the four panel waves from 1998 until 2001. ${ }^{15}$ The sample will be restricted to those living in West Germany, as the East German labour market still has characteristics very different from the West

15. Although newer data are available, the analysis will be restricted to the years before 2002, because there was a major change in German family policy in 2001 which might induce diverging patterns of career interruptions and blur our analyses. 
Table 1

Descriptive Statistics

\begin{tabular}{|c|c|c|c|c|c|c|}
\hline Variable & \multicolumn{2}{|c|}{ A. Overall } & \multicolumn{2}{|c|}{ B. Men } & \multicolumn{2}{|c|}{ C. Women } \\
\hline Continous Variables & & & & & & \\
\hline Gross hourly wage rate (2000 prices) & 14.50 & 7.32 & 16.42 & 7.87 & 12.12 & 5.74 \\
\hline Hours of overtime work & 2.41 & 3.53 & 3.05 & 3.97 & 1.60 & 2.67 \\
\hline Age & 37.55 & 8.95 & 37.83 & 8.61 & 37.20 & 9.34 \\
\hline $\operatorname{Age}^{\wedge} 2$ & 1490.08 & 682.54 & 1505.26 & 663.79 & 1471.22 & 704.78 \\
\hline Years of experience & 14.15 & 8.94 & 15.73 & 9.36 & 12.19 & 7.97 \\
\hline Years of experience $\wedge 2$ & 280.16 & 302.78 & 334.83 & 329.18 & 212.20 & 250.25 \\
\hline \multicolumn{7}{|l|}{ Dummy Variables } \\
\hline Firm size: 1-19 employees & 0.21 & 0.41 & 0.16 & 0.37 & 0.28 & 0.45 \\
\hline Firm size: 20-99 employees & 0.10 & 0.30 & 0.09 & 0.29 & 0.11 & 0.31 \\
\hline Firm size: 100-199 employees & 0.05 & 0.21 & 0.05 & 0.22 & 0.04 & 0.20 \\
\hline Firm size: 200-1999 employees & 0.23 & 0.42 & 0.25 & 0.43 & 0.22 & 0.41 \\
\hline Firm size: more than 2000 employees & 0.26 & 0.44 & 0.30 & 0.46 & 0.21 & 0.41 \\
\hline Public sector employment & 0.28 & 0.45 & 0.25 & 0.43 & 0.33 & 0.47 \\
\hline Firm change & 0.14 & 0.35 & 0.12 & 0.32 & 0.17 & 0.37 \\
\hline Working in high-skilled occupation & 0.46 & 0.50 & 0.45 & 0.50 & 0.47 & 0.50 \\
\hline Gender (male) & 0.55 & 0.50 & & & & \\
\hline Working in predominantly male occupation & 0.40 & 0.49 & 0.63 & 0.48 & 0.11 & 0.31 \\
\hline Working in integrated occupation & 0.28 & 0.45 & 0.26 & 0.44 & 0.31 & 0.46 \\
\hline Working in predominantly femal occupation & 0.32 & 0.47 & 0.11 & 0.31 & 0.58 & 0.49 \\
\hline $\begin{array}{l}\text { Interruption Varlables } \\
\text { Unemployment spells during most recent } 5 \text { yrs. (short run) }\end{array}$ & 0.27 & 0.75 & 0.28 & 0.79 & 0.26 & 0.69 \\
\hline Unemployment spells longer than 5 yrs. ago (long run) & 0.59 & 1.44 & 0.59 & 1.55 & 0.59 & 1.29 \\
\hline Other interruption spells (short run) & 0.07 & 0.30 & 0.06 & 0.28 & 0.08 & 0.31 \\
\hline Other interruption spells (long run) & 0.38 & 1.13 & 0.21 & 0.90 & 0.59 & 1.33 \\
\hline Family-related interruption spells (short run) & 0.60 & 1.35 & 0.09 & 0.45 & 1.23 & 1.77 \\
\hline Family-related interruption spells (long run) & 1.91 & 4.53 & 0.20 & 1.04 & 4.04 & 6.05 \\
\hline \multicolumn{7}{|l|}{ Family-related interruption spells in: } \\
\hline High-skilled occupation (short run) & 0.26 & 0.93 & 0.04 & 0.30 & 0.54 & 1.31 \\
\hline Low-skilled occupation (short run) & 0.34 & 1.06 & 0.05 & 0.35 & 0.69 & 1.47 \\
\hline High-skilled occupation (long run) & 0.77 & 2.97 & 0.09 & 0.78 & 1.62 & 4.21 \\
\hline Low-skilled occupation (long run) & 1.14 & 3.68 & 0.11 & 0.71 & 2.43 & 5.17 \\
\hline High-skilled male occupation (short run) & 0.03 & 0.30 & 0.02 & 0.19 & 0.05 & 0.39 \\
\hline High-skilled integrated occupation (short run) & 0.09 & 0.56 & 0.01 & 0.16 & 0.19 & 0.82 \\
\hline High-skilled female occupation (short run) & 0.14 & 0.71 & 0.01 & 0.17 & 0.30 & 1.02 \\
\hline Low-skilled male occupation (short run) & 0.04 & 0.34 & 0.03 & 0.27 & 0.05 & 0.40 \\
\hline Low-skilled integrated occupation (short run) & 0.08 & 0.54 & 0.01 & 0.17 & 0.17 & 0.78 \\
\hline Low-skilled female occupation (short run) & 0.22 & 0.89 & 0.01 & 0.15 & 0.48 & 1.27 \\
\hline High-skilled male occupation (long run) & 0.09 & 0.93 & 0.05 & 0.65 & 0.14 & 1.20 \\
\hline High-skilled integrated occupation (long run) & 0.25 & 1.73 & 0.02 & 0.35 & 0.53 & 2.54 \\
\hline High-skilled female occupation (long run) & 0.43 & 2.30 & 0.02 & 0.27 & 0.95 & 3.36 \\
\hline Low-skilled male occupation (long run) & 0.11 & 1.09 & 0.06 & 0.49 & 0.18 & 1.53 \\
\hline Low-skilled integrated occupation (long run) & 0.28 & 1.88 & 0.03 & 0.40 & 0.58 & 2.75 \\
\hline Low-skilled female occupation (long run) & 0.75 & 3.07 & 0.02 & 0.32 & 1.66 & 4.42 \\
\hline \# of observations & \multicolumn{2}{|c|}{9257} & \multicolumn{2}{|c|}{5130} & \multicolumn{2}{|c|}{4127} \\
\hline
\end{tabular}

Note: Interruption variables distinguish between short- and long-run. Short-run spells show the number of years in which the individual had an interruption spell within the most recent 5 years. Long-run spells show the number of years with an interruption spell more than five years ago. Real wages are obtained by deflating using the CPI in 2000.

German market. This holds more in general but also when it comes to career interruptions due to family reasons (see e.g. Rosenfeld, Trappe, \& Gornick, 2004). 
Our sample contains all men and women from the age of 20 to 55 who were employed in one or more of the years 1998-2001. All self-employed persons are excluded, as well as those with incomplete data. The sample consists of 9,257 observations, made up of 3,273 individuals from which 1,384 are present in all four waves. All other persons are present in at least one other wave. Descriptive statistics of the variables are shown in table 1 . Note that this sample size only holds for the descriptive statistics and stylised facts. Due to partial nonresponse, the regressions are based on a sample of 8,158 observations, made up of 2,790 individuals.

\section{Description and Construction of Variables}

Hourly wages are reported in Euro and are deflated by the CPI with the year 2000 as reference year (Federal Statistics Office, 2005). Unfortunately, the monthly wage, which is reported by the individuals in the GSOEP questionnaire, includes overtime pay. Since we calculate the hourly wage rate by dividing reported monthly wages by the number of working hours as set in individual contracts, we control for possible overtime pay by including the hours worked overtime in the regressions.

Several standard "Mincer variables" are included. The variable experience counts the years of actual work experience, where every year of full-time employment accumulates the variable value by 1 , and every year in part-time employment accumulates it by 0.5 (cf. Beblo \& Wolf, 2000). In order to capture the generally higher wage for workers in high-skilled occupations, a dummy for being employed in an occupation with high skill requirements is included.16 Wages also differ between the private and public sector of the economy. Accordingly, a dummy for public sector employment is introduced. Moreover, firm size dummies are introduced, with firms employing 1 to 19 employees serving as reference level. Finally, a dummy indicates a worker's change of firms in the year at hand.

16. Note that the dummy does not say anything about the worker's education, but only about the level of the occupation he or she is working in. 


\section{Construction of Occupational Groups}

We construct six occupational groups according to the degree of segregation and the occupation's skill level. In the skill dimension, the occupations are categorised on basis of the reported ISCO-88 codes. Table 2 shows the skill levels of the occupational groups. As in several other studies (see for example Fitzenberger, Schnabel, \& Wunderlich, 2004), we classify occupations that require technical college or university education as high-skilled occupations (3rd and 4th skill level), while jobs requiring a vocational degree and jobs that do not require any degree are classified as medium- and low-skilled occupations, respectively (1st and 2nd skill level). However, due to the very small number of elementary occupations, we pool medium- and low-skilled occupations and denote them together as low-skilled occupations. ${ }^{17}$ With respect to the occupational segregation dimension, there seems to be a consensus in the literature to classify occupations that are comprised of more than two-thirds of female workers as female occupations, occupations with less than one-third as male occupations, and the rest as integrated occupations (cf. Hansen \& Wahlberg, 2000).

Table 2

Skill levels of occupational groups (one-digit ISCO code)

\begin{tabular}{|c|c|c|c|c|}
\hline Level & Skill level & ISCO & Description & Education \\
\hline \multirow{3}{*}{ 竞离 } & $1 \mathrm{st}$ & 9 & Elementary occupations & Primary \\
\hline & 2nd & $4-8$ & $\begin{array}{l}\text { Clerks; } \\
\text { Service workers and shop/market sales workers } \\
\text { Skilled agricultural and fishery workers } \\
\text { Craft and related trades workers } \\
\text { Plant and machine operators and assemblers }\end{array}$ & Vocational \\
\hline & Varying & 0 & Armed forces & \\
\hline \multirow{3}{*}{ 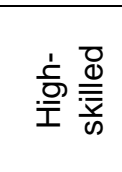 } & 3rd & 3 & Technicians and associate professionals & $\begin{array}{l}\text { Technical } \\
\text { college }\end{array}$ \\
\hline & 4th & 2 & Professionals & University \\
\hline & Varying & 1 & Legislators & \\
\hline
\end{tabular}

Source: ILO (2004), own classification

17. The skill levels of legislators and members of the armed forces vary, but are here classified as high- and low-skilled, respectively (cf. Fitzenberger et al., 2004). 
Note that, in order to classify occupations by their predominant gender, they first have to be distinguished at a particular level of aggregation. This is done on the basis of the three-digit ISCO codes (see table A-1 in the Appendix).

\section{Demarcation of Short- and Long-Run Depreciation Rates}

As found by Mincer and Ofek (1982), wages increase quite rapidly after a career interruption (restoration phase), and settle down to the average level after a while. Therefore, it is sensible to define the short-run as the period starting right after the interruption, and ending when the restoration phase is over. Unfortunately, the existing literature does not offer a consistent estimate of the duration of the restoration phase. Estimates range from recovery after one year (Hesselius, 2003; Light \& Ureta, 1995), to recovery after five years (Mincer \& Ofek, 1982; Nielsen, Simonsen, \& Verner, 2004). However, the two German studies (Beblo \& Wolf, 2002; Kunze, 2002) did not find any evidence of recovery of women's wages after formal parental leave. The interruptions continue to have a negative wage effect even after several years.

Therefore, it is necessary to inspect our own data on these recovery effects. In line with Mincer and Ofek (1982), table 3 displays the current mean hourly wage of those workers who experienced a career interruption due to family reasons in the last five years. The table shows that, although wage growth in the years following an interruption is not as pronounced as in Mincer and Ofek (1982), the average wage is increasing slightly within the first five years (except

for the first year) after the career break, After that period, growth levels off, which indicates the end of the restoration phase. Therefore, we define the shortrun as the first five years after the career interruption. ${ }^{18}$

18. The difference in the length of restoration phase to the other German studies (Beblo \& Wolf, 2002; Kunze, 2002) is remarkable, but possibly due to a different dataset and method. Using the IAB employment panel and the work-history model, they do not find recovery effects of women's wages after parental leave. Note the important difference to our study in measuring the length of the restoration phase: while Beblo \& Wolf and Kunze found that the coefficient for a parental leave spell is significantly negative even several years after the interruption (thus measuring the long-run depreciation effect of parental leave), we look at wage growth after the interruption (thus accurately measuring restoration, incorporating new experience of the worker). 
Table 3

Wage development after a family-related career interruption

\begin{tabular}{cccc}
\hline $\begin{array}{c}\text { Years since last Interruption } \\
\text { (Employed afterwards) }\end{array}$ & $\begin{array}{c}\text { Current average } \\
\text { hourly wage } \\
\text { (2000 prices) }\end{array}$ & $\begin{array}{c}\text { Percentage } \\
\text { Change }\end{array}$ & Obs. \\
\hline 1 & 12.43 & & \\
2 & 12.38 & $0 \%$ & 1044 \\
3 & 12.73 & $3 \%$ & 931 \\
4 & 12.95 & $2 \%$ & 863 \\
5 & 13.36 & $3 \%$ & 774 \\
6 & 13.44 & $1 \%$ & 688 \\
7 & 13.58 & $1 \%$ & 601 \\
8 & 13.41 & $-1 \%$ & 559 \\
\hline
\end{tabular}

Source: GSOEP, using the pooled cross sections 1998-2001, own calculations

\section{Construction of Career Interruption Variables}

We distinguish between three different kinds of career interruptions: (1) career interruptions due to family reasons, (2) career interruptions due to unemployment, and (3) career interruptions due to other reasons. We define "family reasons" as an aggregate of formal parental leave periods and household time. ${ }^{19}$ Career interruptions due to other reasons include sabbaticals, periods of sick leave, or care for elderly family members. Unemployment and other interruption periods are included mainly as controls, but also to compare their wage effects to those of family-related interruptions.

For all three interruption types, a short-run and long-run variable is constructed (e.g. $f a m_{s r}$ and $f a m_{l r}$ ), where "short-run" refers to spells within the last five years and "long-run" refers to spells before that time. Both the short-run and long-run variables contain the number of years, in which a person had an interruption spell. Note that each career interruption appears only once, i.e. either in the short- or long-run variable. We obtain separate estimates for the six occupational groups by interacting $f_{a m}$ and $f a m_{l r}$ with the dummies for highskilled and low-skilled occupations, and with the dummies for male, integrated, and female occupations.

19. Household time means that a person has reported to be a housewife or househusband. 


\section{Some Stylised Facts}

The GSOEP data show us that in West Germany $88.2 \%$ of all family-related employment breaks within the most recent five years were taken by women. ${ }^{20}$ Indeed, only $4.7 \%$ of all working men took an employment break for family reasons within the last five years, compared to $39.8 \%$ of all working women.

Next, it is interesting to check whether workers who interrupt their careers are working in male, female, or integrated occupations because we suspect female occupations to be more suitable for career interruptions. Table 4 shows that the highest fraction of workers with a recent career interruption is indeed found in female occupations. Interestingly, this holds for both women and men. ${ }^{21}$ Whereas $40.1 \%$ of the women employed in the high-skilled female occupations had a family-related career interruption in the last five years, only $29.1 \%$ of the women employed in the high-skilled male occupations had a career break. For the male workers who are employed in these occupations these rates are $7.1 \%$ and $3.9 \%$, respectively. Particularly the latter indicates that it is indeed less costly to have a family-related career break in female occupations.

Table 4

Incidence of family-related career interruptions by occupational

\begin{tabular}{lcccccr}
\hline & $\begin{array}{c}\text { Interruption } \\
(\%)\end{array}$ & $\begin{array}{c}\text { Total } \\
(\#)\end{array}$ & $\begin{array}{c}\text { Interruption } \\
(\%)\end{array}$ & $\begin{array}{c}\text { Total } \\
(\#)\end{array}$ & $\begin{array}{c}\text { Interruption } \\
(\%)\end{array}$ & $\begin{array}{r}\text { Total } \\
(\#)\end{array}$ \\
\hline High-skilled male occupation & 8.7 & 539 & 29.1 & 103 & 3.9 & 436 \\
High-skilled integrated occupation & 20.3 & 497 & 35.5 & 245 & 5.6 & 252 \\
High-skilled female occupation & 32.8 & 445 & 40.1 & 347 & 7.1 & 98 \\
Low-skilled male occupation & 7.5 & 707 & 45.0 & 60 & 4.0 & 647 \\
Low-skilled integrated occupation & 20.8 & 438 & 35.4 & 223 & 5.6 & 215 \\
Low-skilled female occupation & 39.7 & 647 & 44.5 & 564 & 7.2 & 83 \\
& 21.2 & 3,273 & 39.8 & 1,542 & 4.7 & 1,731
\end{tabular}

Source: GSOEP, using the pooled cross sections 1998-2001, own calculations

20. Composition effects should not occur here, since the number of men and women in the sample is almost equal.

21. The only exception are the career interruptions of women in the low-skilled occupations 
Table 5

Most highly segregated occupations

\begin{tabular}{|c|c|c|c|}
\hline ISCO & $\begin{array}{l}\text { Description } \\
\text { Male occupations }\end{array}$ & ISCO & $\begin{array}{l}\text { Description } \\
\text { Female occupations }\end{array}$ \\
\hline 723 & Machinery mechanics and fitters & 419 & Other office clerks \\
\hline 713 & Building finishers and related trades workers & 513 & Personal care and related workers \\
\hline 214 & $\begin{array}{l}\text { Architects, engineers and related } \\
\text { professionals }\end{array}$ & 343 & Administrative associate professionals \\
\hline 311 & $\begin{array}{l}\text { Physical and engineering science } \\
\text { technicians }\end{array}$ & 522 & $\begin{array}{l}\text { Shop, stall and market salespersons and } \\
\text { demonstrators }\end{array}$ \\
\hline 213 & Computing professionals & 913 & $\begin{array}{l}\text { Domestic and related helpers, cleaners } \\
\text { and launderers }\end{array}$ \\
\hline 832 & Motor vehicle drivers & 412 & Numerical clerks \\
\hline 724 & $\begin{array}{l}\text { Electrical and electronic equipment } \\
\text { mechanics and fitters }\end{array}$ & 323 & $\begin{array}{l}\text { Nursing and midwifery associate } \\
\text { professionals }\end{array}$ \\
\hline 712 & Building frame and related trades workers & 411 & Secretaries and keyboard-operating clerk \\
\hline 722 & $\begin{array}{l}\text { Blacksmiths, tool-makers and related trades } \\
\text { workers }\end{array}$ & 344 & $\begin{array}{l}\text { Customs, tax and related government } \\
\text { associate professionals }\end{array}$ \\
\hline
\end{tabular}

Source: GSOEP, using the pooled cross sections 1998-2001, own calculations

We also calculate the Duncan index of dissimilarity for the different occupations in our sample (see Duncan \& Duncan, 1955). We find an index value of 55.9, which means that either $55.9 \%$ of the female workforce would have to switch jobs to male occupations or the other way around in order to achieve complete gender integration in all occupations. Table 5 lists the most highly segregated occupations and therefore represents a good overview of which occupations can be considered "male" or "female".

\section{Model}

We estimate the following fixed-effects model with robust standard errors: $\ln W_{i t}=\beta_{0}+\sum_{j=1}^{6} \delta_{1 j} f_{a m_{i t}^{s r}}^{s r}+\sum_{j=1}^{6} \delta_{2 j}$ fam $_{i t}^{l r}+\eta_{1} u n e m_{i t}^{s r}+\eta_{2}$ unem $_{i t}^{l r}+\gamma_{1} o t h_{i t}^{s r}+\gamma_{2}$ oth $h_{i t}^{l r}+\beta_{1} X_{i t}+\alpha_{i}+\varepsilon_{i t}$

where $W_{i t}$ is the gross hourly wage of individual $i$ at time $t . \delta_{l j}$ represents the human capital depreciation rate of a career interruption due to family reasons in the short-run (i.e. within the last five years) in each of the $j$ occupational groups, as distinguished in hypotheses 1 and 2. Thus, the coefficient $\delta_{11}$ for example, is the depreciation rate of an interruption in a high-skilled male occupation. The coefficient $\delta_{2 j}$ represents the depreciation rate of an interruption in the long-run 
(i.e. the depreciation effect of career interruptions longer than five years ago) in the $j$-th occupational group. ${ }^{22}$ The coefficients $\eta_{1}$ and $\eta_{2}$ measure the human capital depreciation rates of an unemployment spell in the short- or long-run, respectively, and $\gamma_{1}$ and $\gamma_{2}$ measure the short- and long-run depreciation rate of a career interruption due to other reasons, respectively. Note that all coefficients of depreciation rates only measure net depreciation, i.e. it has to be assumed that the interruption periods are not used for further skill-enhancing education.

$X_{i t}$ is a vector of control variables, which includes overtime hours, gender, age, experience, firm size, public or private sector employment, being employed in an occupation with high or low skill requirements, and being employed in a male, female or integrated occupation. Moreover, we included a dummy for firm change. This controls for firm-specific skills obsolescence and occupational mobility. The parameter $\alpha_{i}$ captures individual specific effects, such as ability and motivation (Verbeek, 2004).

A common problem of studies employing panel data is that one might face an attrition bias in the analysis. Normal panel attrition can be considered unproblematic as one might assume that the dropping out of the panel occurs randomly. However, another selection problem might be more relevant in our case: we only observe wages of workers who return into employment after a family-related career break, but not the wages of those who do not re-enter the active workforce. Note that we do not control for this selection problem in this paper. Instead, we claim that our estimates of the depreciation rates rather understate the real depreciation rate, because one might assume that in both male and female occupations, particularly workers with the largest wage penalties do not return into wage employment after a career interruption.

22. A career interruption only appears in either the short-run or the long-run variable. Therefore, multicollinearity is prevented. 


\section{Results}

We estimated three versions of the model presented above, with different variables for family-related career interruptions. Model 1 neither distinguishes between male, integrated, and female occupations in estimating the depreciation rates of family-related career interruptions, nor between the skill levels of the occupations (i.e. high or low skill requirements). This specification will help to show Mincer and Ofek's (1982) restoration effect, and allows comparisons to the coefficients of career interruptions due to unemployment and other reasons. Model 2 does distinguish between skill levels, but does not distinguish between male, integrated, and female occupations. This specification will show interesting gender differences in depreciation rates. Finally, model 3 represents the full model of equation (4). ${ }^{23}$

The estimation results are shown in table 6. The estimation results of model 1 show the overall wage effect of career interruptions. All regression coefficients have the expected signs. Short-term effects of career interruptions are higher than the effect of career interruptions lying longer in the past. This supports Mincer and Ofek's (1982) observation of a restoration phase.

It is also interesting to compare the depreciation rates during family-related career interruptions with the depreciation rates during unemployment and other career interruptions because the motivation for each of these interruption types is entirely different and might therefore give different signals to the employer (Albrecht et al., 1999). The estimation results show that the short-term depreciation rate after a career break due to family reasons is smaller than the short-term depreciation rate after career breaks due to unemployment or other reasons. Moreover, the differences between short- and long-run effects are much more pronounced after unemployment and career breaks for other reasons. While the negative long-run effects after unemployment is less strong than for family-related interruptions, the short-term effects are much stronger (e.g. $-4 \%$ for unemployment).

23. Individuals with hourly wage rates higher than 100 Euros are excluded from the regressions because their data are likely to be unreliable. Moreover, everybody who reported a family-related career interruption but has never worked before is excluded from the regressions as well. 
Table 6

Estimation results of fixed effects regressions on log gross hourly wages

\begin{tabular}{|c|c|c|c|c|c|c|c|c|c|}
\hline & \multicolumn{3}{|c|}{ A. Overall. } & \multicolumn{3}{|c|}{ B. Women } & \multicolumn{3}{|c|}{ C. Men } \\
\hline & Model (1) & Model (2) & Model (3) & Model (1) & Model (2) & Model (3) & Model (1) & Model (2) & Model (3) \\
\hline Hours of overtime work & $\begin{array}{c}0.006^{* * *} \\
(0.001)\end{array}$ & $\begin{array}{c}0.006^{* * *} \\
(0.001)\end{array}$ & $\begin{array}{c}0.006^{* * *} \\
(0.001)\end{array}$ & $\begin{array}{c}0.007 * * * \\
(0.002)\end{array}$ & $\begin{array}{c}0.007^{* * *} \\
(0.002)\end{array}$ & $\begin{array}{c}0.007^{* * *} \\
(0.002)\end{array}$ & $\begin{array}{c}0.005^{* * *} \\
(0.001)\end{array}$ & $\begin{array}{c}0.005^{* * *} \\
(0.001)\end{array}$ & $\begin{array}{c}0.005^{* * *} \\
(0.001)\end{array}$ \\
\hline Working in high-skilled occupation & $\begin{array}{l}0.026^{*} \\
(0.015)\end{array}$ & $\begin{array}{l}0.032 * \\
(0.017)\end{array}$ & $\begin{array}{l}0.028 * \\
(0.017)\end{array}$ & $\begin{array}{c}0.014 \\
(0.024)\end{array}$ & $\begin{array}{c}0.019 \\
(0.034)\end{array}$ & $\begin{array}{c}0.002 \\
(0.035)\end{array}$ & $\begin{array}{c}0.040 * * \\
(0.017)\end{array}$ & $\begin{array}{c}0.037 * * \\
(0.017)\end{array}$ & $\begin{array}{c}0.039 * * \\
(0.017)\end{array}$ \\
\hline Working in male occupation & $\begin{array}{c}0.025 \\
(0.019)\end{array}$ & $\begin{array}{c}0.024 \\
(0.019)\end{array}$ & $\begin{array}{c}0.053 * * \\
(0.021)\end{array}$ & $\begin{array}{c}0.003 \\
(0.037)\end{array}$ & $\begin{array}{c}0.002 \\
(0.037)\end{array}$ & $\begin{array}{c}0.069 \\
(0.049)\end{array}$ & $\begin{array}{c}0.028 \\
(0.023)\end{array}$ & $\begin{array}{c}0.026 \\
(0.023)\end{array}$ & $\begin{array}{l}0.040^{*} \\
(0.024)\end{array}$ \\
\hline Working in integrated occupation & $\begin{array}{c}0.024 \\
(0.016)\end{array}$ & $\begin{array}{c}0.023 \\
(0.016)\end{array}$ & $\begin{array}{c}0.041^{* *} \\
(0.018)\end{array}$ & $\begin{array}{c}0.034 \\
(0.022)\end{array}$ & $\begin{array}{c}0.033 \\
(0.023)\end{array}$ & $\begin{array}{c}0.072 * * \\
(0.029)\end{array}$ & $\begin{array}{c}0.016 \\
(0.022)\end{array}$ & $\begin{array}{c}0.016 \\
(0.022)\end{array}$ & $\begin{array}{c}0.022 \\
(0.023)\end{array}$ \\
\hline Working in public sector & $\begin{array}{l}-0.016 \\
(0.017)\end{array}$ & $\begin{array}{l}-0.016 \\
(0.017)\end{array}$ & $\begin{array}{l}-0.017 \\
(0.017)\end{array}$ & $\begin{array}{l}-0.019 \\
(0.025)\end{array}$ & $\begin{array}{l}-0.019 \\
(0.025)\end{array}$ & $\begin{array}{l}-0.019 \\
(0.025)\end{array}$ & $\begin{array}{l}-0.009 \\
(0.021)\end{array}$ & $\begin{array}{l}-0.011 \\
(0.021)\end{array}$ & $\begin{array}{l}-0.016 \\
(0.021)\end{array}$ \\
\hline Age & $\begin{array}{c}0.076 * * * \\
(0.028)\end{array}$ & $\begin{array}{c}0.077^{* * *} \\
(0.028)\end{array}$ & $\begin{array}{c}0.076 * * * \\
(0.028)\end{array}$ & $\begin{array}{c}0.059 \\
(0.038)\end{array}$ & $\begin{array}{c}0.060 \\
(0.038)\end{array}$ & $\begin{array}{c}0.058 \\
(0.038)\end{array}$ & $\begin{array}{c}0.101 * * \\
(0.041)\end{array}$ & $\begin{array}{c}0.101^{* *} \\
(0.041)\end{array}$ & $\begin{array}{c}0.101^{* *} \\
(0.041)\end{array}$ \\
\hline $\operatorname{Age}^{\wedge} 2$ & $\begin{array}{c}-0.001 * * * \\
(0.000)\end{array}$ & $\begin{array}{c}-0.001^{* * *} \\
(0.000)\end{array}$ & $\begin{array}{c}-0.001^{* * * *} \\
(0.000)\end{array}$ & $\begin{array}{c}-0.001^{* *} \\
(0.000)\end{array}$ & $\begin{array}{c}-0.001^{* *} \\
(0.000)\end{array}$ & $\begin{array}{c}-0.001^{* *} \\
(0.000)\end{array}$ & $\begin{array}{l}-0.001 * \\
(0.000)\end{array}$ & $\begin{array}{l}-0.001 * \\
(0.000)\end{array}$ & $\begin{array}{l}-0.001 * \\
(0.000)\end{array}$ \\
\hline Firm size: $20-99$ e & $\begin{array}{c}0.008 \\
(0.011)\end{array}$ & $\begin{array}{c}0.008 \\
(0.011)\end{array}$ & $\begin{array}{c}0.007 \\
(0.011)\end{array}$ & $\begin{array}{c}0.007 \\
(0.019)\end{array}$ & $\begin{array}{c}0.007 \\
(0.019)\end{array}$ & $\begin{array}{c}0.006 \\
(0.018)\end{array}$ & $\begin{array}{c}0.010 \\
(0.014)\end{array}$ & $\begin{array}{c}0.009 \\
(0.014)\end{array}$ & $\begin{array}{c}0.007 \\
(0.014)\end{array}$ \\
\hline Firm size: 100-199 employees & $\begin{array}{c}0.011 \\
(0.013)\end{array}$ & $\begin{array}{c}0.011 \\
(0.013)\end{array}$ & $\begin{array}{c}0.009 \\
(0.013)\end{array}$ & $\begin{array}{c}0.014 \\
(0.025)\end{array}$ & $\begin{array}{c}0.014 \\
(0.025)\end{array}$ & $\begin{array}{c}0.013 \\
(0.026)\end{array}$ & $\begin{array}{c}0.005 \\
(0.014)\end{array}$ & $\begin{array}{c}0.005 \\
(0.014)\end{array}$ & $\begin{array}{c}0.004 \\
(0.014)\end{array}$ \\
\hline Firm size: 200-1999 em & $\begin{array}{c}0.029 * * \\
(0.014)\end{array}$ & $\begin{array}{c}0.029 * * \\
(0.014)\end{array}$ & $\begin{array}{c}0.031^{* *} \\
(0.014)\end{array}$ & $\begin{array}{c}0.060 * * \\
(0.025)\end{array}$ & $\begin{array}{c}0.061^{* *} \\
(0.025)\end{array}$ & $\begin{array}{c}0.067^{* * *} \\
(0.024)\end{array}$ & $\begin{array}{l}-0.006 \\
(0.016)\end{array}$ & $\begin{array}{l}-0.005 \\
(0.016)\end{array}$ & $\begin{array}{l}-0.003 \\
(0.016)\end{array}$ \\
\hline Firm size: more than 2000 employees & $\begin{array}{c}0.044 * * \\
(0.017)\end{array}$ & $\begin{array}{c}0.044 * * \\
(0.017)\end{array}$ & $\begin{array}{c}0.045^{* * *} \\
(0.017)\end{array}$ & $\begin{array}{c}0.091 * * * \\
(0.031)\end{array}$ & $\begin{array}{c}0.090 * * * \\
(0.031)\end{array}$ & $\begin{array}{c}0.091 * * * \\
(0.031)\end{array}$ & $\begin{array}{c}0.003 \\
(0.018)\end{array}$ & $\begin{array}{c}0.004 \\
(0.018)\end{array}$ & $\begin{array}{c}0.004 \\
(0.018)\end{array}$ \\
\hline Firm change & $\begin{array}{l}-0.005 \\
(0.010)\end{array}$ & $\begin{array}{l}-0.005 \\
(0.010)\end{array}$ & $\begin{array}{l}-0.004 \\
(0.010)\end{array}$ & $\begin{array}{l}-0.025 \\
(0.018)\end{array}$ & $\begin{array}{l}-0.024 \\
(0.018)\end{array}$ & $\begin{array}{l}-0.023 \\
(0.018)\end{array}$ & $\begin{array}{c}0.014 \\
(0.011)\end{array}$ & $\begin{array}{c}0.014 \\
(0.011)\end{array}$ & $\begin{array}{c}0.015 \\
(0.011)\end{array}$ \\
\hline Years of experience & $\begin{array}{c}0.027 \\
(0.018)\end{array}$ & $\begin{array}{c}0.026 \\
(0.018)\end{array}$ & $\begin{array}{c}0.026 \\
(0.018)\end{array}$ & $\begin{array}{l}0.044 * \\
(0.024)\end{array}$ & $\begin{array}{l}0.043^{*} \\
(0.024)\end{array}$ & $\begin{array}{l}0.043^{*} \\
(0.024)\end{array}$ & $\begin{array}{l}-0.008 \\
(0.028)\end{array}$ & $\begin{array}{l}-0.008 \\
(0.028)\end{array}$ & $\begin{array}{l}-0.011 \\
(0.028)\end{array}$ \\
\hline Years of experience $\wedge 2$ & $\begin{array}{l}-0.000 \\
(0.000)\end{array}$ & $\begin{array}{l}-0.000 \\
(0.000)\end{array}$ & $\begin{array}{l}-0.000 \\
(0.000)\end{array}$ & $\begin{array}{l}-0.000 \\
(0.000)\end{array}$ & $\begin{array}{l}-0.000 \\
(0.000)\end{array}$ & $\begin{array}{l}-0.000 \\
(0.000)\end{array}$ & $\begin{array}{l}-0.001 \\
(0.000)\end{array}$ & $\begin{array}{l}-0.001 \\
(0.000)\end{array}$ & $\begin{array}{l}-0.001 \\
(0.000)\end{array}$ \\
\hline Unem! & $\begin{array}{c}-0.040 * * \\
(0.020)\end{array}$ & $\begin{array}{c}-0.040^{* *} \\
(0.020)\end{array}$ & $\begin{array}{c}-0.039 * * \\
(0.020)\end{array}$ & $\begin{array}{c}-0.057 * * \\
(0.028)\end{array}$ & $\begin{array}{c}-0.056 * * \\
(0.028)\end{array}$ & $\begin{array}{l}-0.054 * \\
(0.029)\end{array}$ & $\begin{array}{l}-0.028 \\
(0.027)\end{array}$ & $\begin{array}{l}-0.028 \\
(0.027)\end{array}$ & $\begin{array}{l}-0.030 \\
(0.027)\end{array}$ \\
\hline Unemployment spell (long term) & $\begin{array}{l}-0.004 \\
(0.021)\end{array}$ & $\begin{array}{l}-0.003 \\
(0.021)\end{array}$ & $\begin{array}{l}-0.003 \\
(0.022)\end{array}$ & $\begin{array}{l}-0.024 \\
(0.031)\end{array}$ & $\begin{array}{l}-0.023 \\
(0.031)\end{array}$ & $\begin{array}{l}-0.022 \\
(0.032)\end{array}$ & $\begin{array}{c}0.011 \\
(0.029)\end{array}$ & $\begin{array}{c}0.013 \\
(0.029)\end{array}$ & $\begin{array}{c}0.015 \\
(0.028)\end{array}$ \\
\hline Other interruption spell (short term) & $\begin{array}{l}-0.040 * \\
(0.023)\end{array}$ & $\begin{array}{l}-0.041 * \\
(0.023)\end{array}$ & $\begin{array}{l}-0.040 * \\
(0.023)\end{array}$ & $\begin{array}{l}-0.040 \\
(0.035)\end{array}$ & $\begin{array}{l}-0.040 \\
(0.035)\end{array}$ & $\begin{array}{l}-0.043 \\
(0.035)\end{array}$ & $\begin{array}{l}-0.020 \\
(0.032)\end{array}$ & $\begin{array}{l}-0.020 \\
(0.032)\end{array}$ & $\begin{array}{l}-0.017 \\
(0.032)\end{array}$ \\
\hline uption spell (long term) & $\begin{array}{l}-0.021 \\
(0.015)\end{array}$ & $\begin{array}{l}-0.022 \\
(0.015)\end{array}$ & $\begin{array}{l}-0.021 \\
(0.016)\end{array}$ & $\begin{array}{l}-0.017 \\
(0.018)\end{array}$ & $\begin{array}{l}-0.018 \\
(0.018)\end{array}$ & $\begin{array}{l}-0.017 \\
(0.018)\end{array}$ & $\begin{array}{c}0.020 \\
(0.031)\end{array}$ & $\begin{array}{c}0.019 \\
(0.031)\end{array}$ & $\begin{array}{c}0.014 \\
(0.031)\end{array}$ \\
\hline $\begin{array}{l}\text { Family-related interruption spell } \\
\text { (short term) }\end{array}$ & $-0.018^{*}$ & & & -0.013 & & & -0.038 & & \\
\hline $\begin{array}{l}\text { Family-related interruption spell } \\
\text { (long term) }\end{array}$ & $\begin{array}{l}-0.011 \\
(0.009)\end{array}$ & & & $(0.011)$ & & & $\begin{array}{l}-0.027 \\
(0.020)\end{array}$ & & \\
\hline 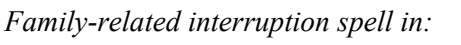 & & & & & & & & & \\
\hline High-skilled occupation (short term) & & $\begin{array}{l}-0.023 * \\
(0.012)\end{array}$ & & & $\begin{array}{l}-0.017 \\
(0.013)\end{array}$ & & & $\begin{array}{l}-0.051 \\
(0.038)\end{array}$ & \\
\hline Low-skilled occupation (short term) & & $\begin{array}{l}-0.013 \\
(0.012)\end{array}$ & & & $\begin{array}{l}-0.011 \\
(0.013)\end{array}$ & & & $\begin{array}{l}-0.028 \\
(0.031)\end{array}$ & \\
\hline
\end{tabular}


Table 6 (continued)

Estimation results of fixed effects regressions on log gross hourly wages

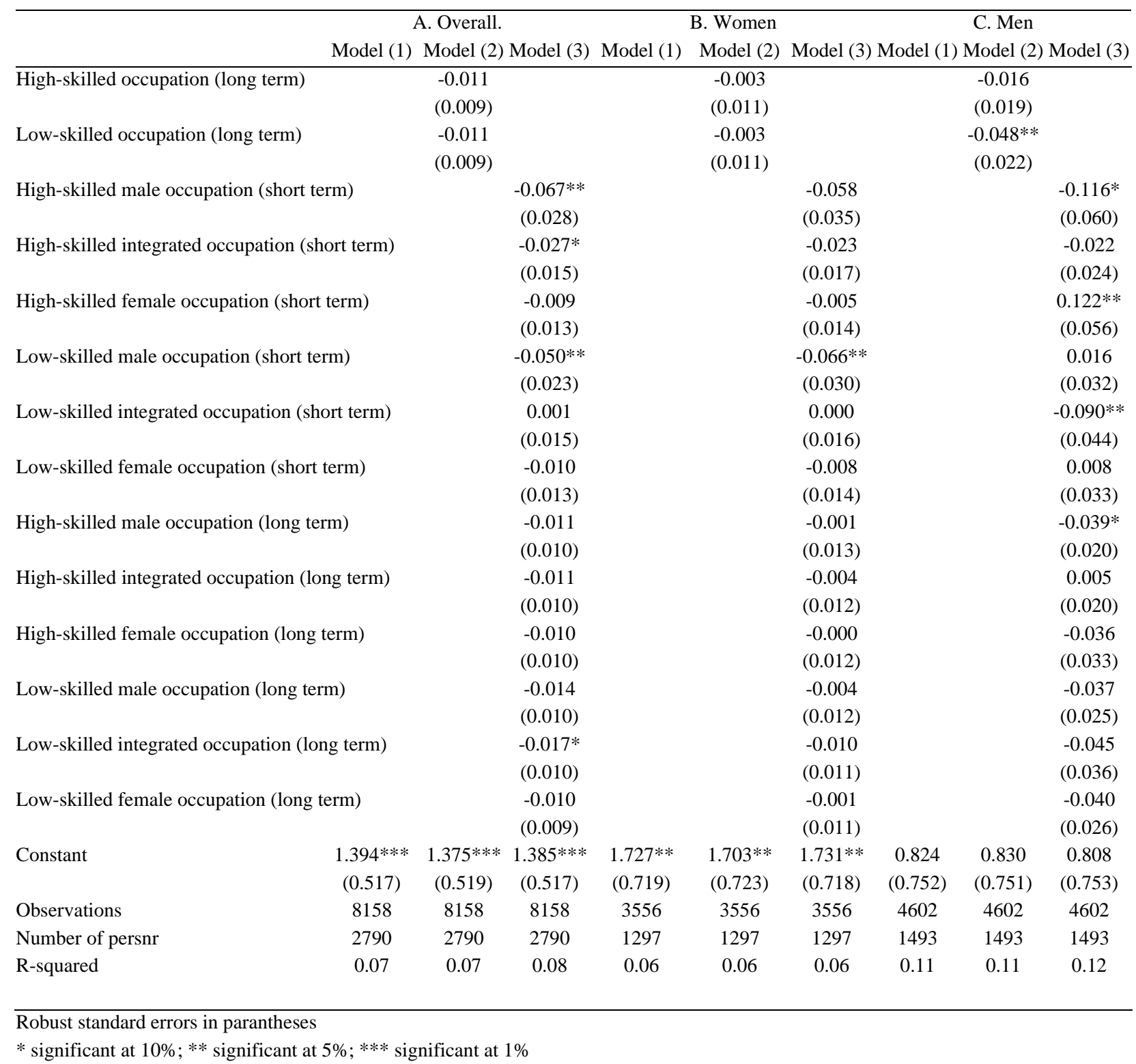

These results contradict the findings by Beblo and Wolf (2002, 2003) and Kunze (2002) who find that formal parental leave has a stronger wage effect than types of interruptions other than unemployment. ${ }^{24}$ Beblo and Wolf interpret

24. A possible explanation for this difference in results seems to lie in the different data sets used. Beblo \& Wolf and Kunze use the IAB employment panel, which includes only full-time employees in the private sector, while our GSOEP data includes also part-time employees and public sector employees. If we expect lower wage penalties in the public sector, this might explain 
this result as a negative stigma effect attached to parental leave. Yet, our results suggest a stigma effect attached to unemployment periods, which makes more sense intuitively because a period of unemployment conveys a much more negative signal to employers than a period on parental leave (cf. Albrecht et al., 1999). Although unemployed persons may not suffer from stronger skills obsolescence due to the career interruption than workers on family-related leave, their wages decline much more in the short-run because employers may stigmatise unemployed people as less qualified or less motivated. Moreover, unemployed workers might indeed be low productivity workers who have been selectively laid off by their former employer (Gibbons \& Katz, 1991).

However, the strong negative wage effect of an unemployment spell - and thus the stigmatisation - vanishes as the worker becomes re-integrated into workforce, as can be seen from the lower long-run effects. Obviously, the much smaller difference between the short-term and long-term wage effects of familyrelated career interruption indicates that there is hardly any stigma effect for this type of interruption. This means that the effects measured show the true effect of human capital obsolescence due to the career interruption.

Model 2 enables us to distinguish between depreciation rates in occupations with high and low skill requirements. It is not clear though whether human capital depreciation should be higher in high- or in low-skilled occupations. ${ }^{25}$ The estimation results for the overall sample show a stronger short-term depreciation in high-skilled occupations. Depreciation rates are insignificant in

our lower depreciation rates. Yet, running separate regressions for the private and public sector shows that there are hardly any significant differences in depreciation between the sectors.

25. On the one hand, depreciation in occupations with high skill requirements might be higher, because high-skilled workers simply have more human capital to lose (Beblo \& Wolf, 2000), and might be more strongly exposed to technological change (Neuman \& Weiss, 1995). On the other hand, depreciation in occupations with low skill requirements could be higher, especially if one takes into account that workers employed in low-skilled occupations in our sample still need a certain amount of skills. Due to the high coverage of vocational training in Germany, their skills are often specific to their occupation, and may therefore be more vulnerable to depreciation during career interruptions than the general skills of workers in high-skilled occupations. In addition, the market value of vocational skills is probably strongly affected by technological change. 
the male and female sample, except for the long-run depreciation rate for men employed in low-skilled occupations.

Model 3 enables us to test hypotheses 1 and 2. The estimation results show that - in occupations with high skill requirements - the short-run depreciation rate for an additional year of family-related absence is estimated to be more than 6 percentage-points higher in male occupations than in female occupations. The difference is statistically significant (see table 7). The estimation results for occupations with low skill requirements are similar: the short-run depreciation rate in male occupations is 4 percentage-points higher than in female occupations. However, the difference is only weakly significant at a $10 \%$ level.

Table 7

Results of the Wald test for equality of coefficients ( $\delta$ male $=(\delta$ female $)$

\begin{tabular}{|c|c|c|c|c|c|c|c|c|}
\hline & & \multicolumn{2}{|c|}{ A. Overall } & B. & Women & C. & Men & Hypothesis \\
\hline \multirow{4}{*}{$\begin{array}{l}\text { Short- } \\
\text { term }\end{array}$} & High-skilled & $\mathrm{F}$ & 4.59 & $\mathrm{~F}$ & 2.38 & $\mathrm{~F}$ & 11.83 & \multirow{2}{*}{$\# 1$} \\
\hline & \multirow{3}{*}{ Low-skilled } & $p$ & 0.032 & $p$ & 0.123 & $p$ & 0.00 & \\
\hline & & $\mathrm{F}$ & 2.68 & $\mathrm{~F}$ & 3.45 & $\mathrm{~F}$ & 0.08 & \multirow{2}{*}{ \#2 } \\
\hline & & $\mathrm{p}$ & 0.102 & $\mathrm{p}$ & 0.063 & $\mathrm{p}$ & 0.77 & \\
\hline \multirow{4}{*}{$\begin{array}{l}\text { Long- } \\
\text { term }\end{array}$} & High-skilled & $\mathrm{F}$ & 0.01 & $\mathrm{~F}$ & 0.01 & $\mathrm{~F}$ & 0.01 & \multirow{2}{*}{ \#1 } \\
\hline & & $\mathrm{p}$ & 0.917 & $\mathrm{p}$ & 0.917 & $p$ & 0.928 & \\
\hline & Low-skilled & $\mathrm{F}$ & 0.57 & $\mathrm{~F}$ & 0.19 & $\mathrm{~F}$ & 0.01 & \multirow{2}{*}{ \#2 } \\
\hline & & $\mathrm{p}$ & 0.452 & $\mathrm{p}$ & 0.67 & $p$ & 0.92 & \\
\hline
\end{tabular}

When we look at short-term depreciation rates during family-related career interruptions in the female sample, we find a significantly higher depreciation rate in low-skilled male occupations. In these low-skilled occupations, depreciation rates are 6 percentage points higher in male occupations than in female occupations. The Wald test of equal coefficients allows rejection of the Null hypothesis (see table 7). For the high-skilled occupations, the difference between the male and female occupations is approximately 5 percentage points. However, the Wald test of equal coefficients only allows rejection of the Null hypothesis at a $12 \%$ level.

The short-term depreciation rates during family-related career breaks for highskilled men show that men who are employed in a high-skilled male occupation face a very large short-run wage penalty when they have had a career break 
(11.6\%). This may indicate that these men are stigmatised as being less motivated and career-oriented (cf. Albrecht et al., 2001), which might explain the reluctance of most men employed in these jobs to have a family-related career interruption. Moreover, we find that male workers who are employed in male occupations also face a wage penalty in the long run when they have had a family-related career break

To sum up, we find support for hypotheses 1 and 2 in the short run, with the exception of low-skilled occupations in the male sample. These results support Polachek's (1981) hypothesis of occupational self-selection due to differences in human capital depreciation rates.

However, the estimation results for long-run depreciation rates only show a significant negative wage effects for low-skilled integrated occupations in the overall sample, and the high-skilled male workers who are employed in the male occupations. For women long-term depreciation rates in the six occupational categories are clearly very close to zero. Again, higher wage penalties for men can be interpreted in line with the stigmatisation argument mentioned previously. While insignificant long-term wage effects of familyrelated career interruptions suggest that the long-term effects of family-related career breaks are not important for occupational choice, the short-term effects will probably still be taken into account when workers make their choice in order to maximise life-time earnings. Yet, the rather high short-term wage penalty in male occupations gives a sufficient explanation for occupational choice.

\section{Conclusion and Discussion}

In this paper we estimated human capital depreciation rates due to career interruptions for family reasons on the West German labour market. Opposite to other studies, we focus on human capital depreciation during career interruptions due to family reasons. The rationale for this confinement is that interruptions due to family reasons are the only type of career interruption, which can be taken into account when women choose their occupational field. 
Moreover, our study differs from most other studies by estimating both shortand long-run human capital depreciation rates.

We estimated a fixed effects model for West Germany from the German Socioeconomic Panel (GSOEP), and determined depreciation rates for six occupational groups (male, integrated, and female occupations with high and low skill requirements, respectively). Our results for short run depreciation are supportive to our hypothesis that human capital depreciation rates during family-related career interruptions are lower in female occupations than in male occupations. This holds for both high- and low-skilled occupations in the overall and female sample, and for high-skilled occupations in the male sample. However, long-term depreciation rates are found to be statistically insignificant for both male and female occupations, except for high-skilled men who have had a family-related career break.in a male occupation.

These findings show that different human capital depreciation rates in the various occupational fields can explain at least part of the occupational sex segregation in Germany, as our findings support the theory of occupational selfselection. This theory argues that women who anticipate career interruptions for family reasons take account of the wage penalties related to such a break when they choose their occupational field, i.e. women select occupations where human capital deprecation during a career interruption is the lowest. Our results are also consistent with other studies that state other reasons why women might self-select into female occupations, such as flexibility, more part-time options, or more pleasant working conditions, because our depreciation rates can be interpreted as the compensating wage differential subtracted from a worker's pay for taking advantage of amenities after the career interruption.

Our estimation results have important implications for public policies which attempt to encourage the interest of female students in technical studies and occupations. Obviously, the higher human-capital depreciation rates for workers with family-related career breaks in these male occupations can be a serious threshold for women to choose these occupations (cf. De Grip and Willems, 2003). 
Our estimation results contradict the findings by England (1982) and Kunze (2002). Both authors find that depreciation rates are higher in female occupations. England's results may be different because she included all types of career interruptions, whereas we focus on interruptions due to family reasons. Moreover, her analysis referred the U.S. where the institutional setting and tradition for family leave is different to Germany's. The differences with Kunze's study are more remarkable, however, because she also analysed family-related career interruptions on the German labour market. Using a different data set, she found very pronounced negative wage effects for women in female occupations on parental leave. However, as mentioned, she only took account of registered maternity and parental leave, including long-term sick leave, whereas we used a broader definition of family-related career interruptions. Moreover, Kunze focuses on young full-time workers who participated in apprenticeship training in the private sector, excluding those with higher education.

It should be noted that our analysis did not address the question of causality between differences in human capital depreciation rates and occupational selfselection, i.e. our results only support the occupational self-selection theory when women who expect career interruptions due to family reasons take depreciation rates into account ex ante, i.e. before they choose an occupation. Yet, it might also be possible that women only "discover" ex post, i.e. after having made the choice that depreciation rates in their occupation are low, and for that reason more easily decide to go on family leave. Furthermore, it could be that depreciation rates in female occupations are that low precisely because so many workers in these jobs go have family-related career breaks. Note that such an interpretation would imply that we do not observe true skills obsolescence, but that the observed wage effects are rather mirroring the adjustment costs to the employers (cf. Ondrich et al., 2002). However, when that is the case, the lower depreciation rates in female occupations can still reinforce gender segregation, because of the prevailing lower depreciation rates in female occupations. Moreover, some of our evidence contradicts the argument that depreciation rates only reflect adjustment costs, as we found that workers with a career break due to unemployment face a much larger short-run wage penalty than those with a family-related career break. Also the much smaller difference between the short-term and long-term wage effects for 
family-related career interruption indicates that the effects measured show the true effect of human capital obsolescence due to the career interruption.

For future research, we think it would be interesting to estimate depreciation rates, which are truly occupation-specific, i.e. estimating separate depreciation rates for teachers, secretaries, physicians, etc. With those results, one could make even stronger conclusions about the connection between depreciation rates and occupational sex segregation. 


\section{References}

Albrecht, J.W., Edin, P.-A., Sundström, M., \& Vroman, S.B. (1999). Career Interruptions and Subsequent Earnings: A Reexamination Using Swedish Data. Journal of Human Resources, 34(2), 294-311.

Beblo, M., \& Wolf, E. (2000). How Much Does a Year Of Cost?: Estimating the Wage Efects of Employment Breaks and Part-Time Periods (Discussion Paper 00-69). Mannheim: ZEW.

Beblo, M., \& Wolf, E. (2002). Wage Penalties for Career Interruptions: An Empirical Analysis for West Germany (Discussion Paper No. 02-45). Mannheim: ZEW.

Beblo, M., \& Wolf, E. (2003). Sind es die Erwerbsunterbrechungen? Ein Erklärungsbeitrag zum Lohnunterschied zwischen Frauen und Männern in Deutschland. (Is It the Employment Interruptions? A Contribution to Explaining the Wage Differentials between Men and Women in Germany. With English summary.). Mitteilungen aus Berufs- und Arbeitsmarktforschung, 36(4), 560-572.

Beller, A.H. (1982). Occupational segregation by sex: determinants and changes. Journal of Human Resources, 17,371-392.

Bender, K. A., Donohue, S. M., \& Heywood, J. S. (2005). Job Satisfaction and Gender Segregation. Oxford Economic Papers, 57, 479-496.

Boisso, D. (1994). Occupational segregation in the multidimensional case: decomposition and tests of significance. Journal of Econometrics, 61, 161-171.

Borghans, L. \& Groot, L. (1999). Educational presorting and occupational segregation. Labour Economics, 6, 375-395.

Charles, M. (2003). Deciphering Sex Segregation: Vertical and Horizontal Inequalities in Ten National Labor Markets. Acta Sociologica, 46(4), 267-287.

Datta Gupta, N., \& Smith, N. (2000). Children and Career Interruptions: The Family Gap in Denmark (CLS Working Papers 00-3). Aarhus: Aarhus School of Business, Centre for Labour Market and Social Research.

Datta Gupta, N., \& Smith, N. (2002). Children and Career Interruptions: The Family Gap in Denmark. Economica, 69, 609-629.

De Grip, A., \& Van Loo, J. (2002). The Economics of Skills Obsolescence: A Review. The Economics of Skills Obsolescence, 21, 1-26.

De Grip, A. \& Willems, E. (2003). Youngsters and Technology. Research Policy, 32, 1771-1781.

Deutsch, J. \& Silber, J. (2005). Comparing segregation by gender in the labor force across ten European countries in the 1990s: An analysis based on the use of normative segregation indices. International Journal of Manpower, 26, 237-264.

Duncan, O.D. \& Duncan, B. (1955). A methodological analysis of segregation indexes. American Sociological Review, 20, 210-217.

England, P. (1982). The Failure of Human Capital Theory to Explain Occupational Sex Segregation. Journal of Human Resources, 17(3), 358-370. 
Fain, J. R. (1998). The Causes and Consequences of Occupational Segregation: A Simultaneous Equations Approach. Applied Economics, 30(10), 1361-1367.

Federal Statistics Office. (2005). Time Series - Prices. Retrieved February 22, 2005, from http://www.destatis.de/indicators/e/lrleb02ae.htm

Filer, R. K. (1985). Male-Female Wage Differences: The Importance of Compensating Differentials. Industrial and Labor Relations Review, 38(3), 426-437.

Fitzenberger, B., Schnabel, R., \& Wunderlich, G. (2004). The gender gap in labor market participation and employment: A cohort analysis for West Germany. Journal of Population Economics, 17, 83-116.

Gibbons, R., \& Katz, L.F. (1991). Layoffs and Lemons. Journal of Labor Economics, 9(4), 351-380.

Gronau, R. (1988). Sex-Related Differentials and Women's Interrupted Labor Careers - the Chicken or the Egg. Journal of Labor Economics, 6(3), 277-301.

Groot, W., \& Maassen van den Brink, H. (2000). Overeducation in the Labor Market: A Metaanalysis. Economics of Education Review 19, 149-158.

Hansen, J., \& Wahlberg, R. (2000). Occupational Gender Composition and Wages in Sweden (Discussion Paper No. 217). Bonn: IZA.

Hashimoto, M., Percy, R., Schoellner, T., \& Weinberg, B. A. (2004). The Long and Short of it: Maternity Leave Coverage and Women's Labor Market Outcomes (Working Paper). Columbus, Ohio: The Ohio State University.

Hesselius, P. (2003). Sick Absence and Subsequent Wages (mimeo). Uppsala: Uppsala University.

ILO. (2004). ISCO - Conceptual Framework. Retrieved 17 December, 2004, from http://www.ilo.org/public/english/bureau/stat/isco/isco88/index1.htm

Jacobsen, J. P. (1998). The economics of gender (2nd[upd.] ed.). Malden, MA [etc.]: Blackwell.

Jurajda, S., \& Harmgart, H. (2003). When Are 'Female' Occupations Paying More? (Working Paper http://www.cerge-ei.cz/pdf/wp/Wp202.pdf). Prague: CERGE-EI.

Karmel, T. \& Machlachlan, M. (1988). Occupational sex segregation. Increasing or decreasing? Economic Record, 64, 187-195.

Kim, M.-K., \& Polachek, S.W. (1994). Panel Estimates of Male-Female Earnings Functions. The Journal of Human Resources, 29(2, Special Issue: Women's Work, Wages, and Well-Being), 406428.

Kunze, A. (2002). The Timing of Careers and Human Capital Depreciation (IZA Discussion Paper No. 509). Bonn: IZA.

Lewis, D. E., \& Shorten, B. (1991). Occupational Segregation, Labour Force Participation and the Relative Earnings of Men and Women. Applied Economics, 23(1), 167-177.

Light, A., \& Ureta, M. (1995). Early-Career Work Experience and Gender Wage Differentials. Journal of Labor Economics, 13(1), 121-154. 
McDowell, J. M. (1982). Obsolescence of Knowledge and Career Publication Profiles: Some Evidence of Differences among Fields in Costs of Interrupted Careers. The American Economic Review, 72(4), 752-768.

Mincer, J. (1974). Schooling, Experience and Earnings. New York: Columbia University Press.

Mincer, J., \& Ofek, H. (1982). Interrupted Work Careers: Depreciation and Restoration of Human Capital. The Journal of Human Resources, 17(1), 3-24.

Mincer, J., \& Polachek, S. (1974). Family Investments in Human Capital: Earnings of Women. The Journal of Political Economy, 82(2), Part 2: Marriage, Family Human Capital, and Fertility), S76S108.

Mincer, J., \& Polachek, S. (1978). An Exchange: The Theory of Human Capital and the Earnings of Women: Women's Earnings Reexamined. Journal of Human Resources, 13(1), 118-134.

Neuman, S., \& Weiss, A. (1995). On the Effects of Schooling Vintage on Experience-Earnings Profiles: Theory and Evidence. European Economic Review, 39(5), 943-955.

Nielsen, H. S., Simonsen, M., \& Verner, M. (2004). Does the Gap in Family-friendly Policies Drive the Family Gap? (Working Paper). Aarhus: Department of Economics, University of Aarhus.

Ondrich, J., Spiess, C. K., \& Yang, Q. (2002). The Effects of Maternity Leave on Women's Pay in Germany 1984-1994 (Discussion Paper 289). Berlin: DIW.

Polachek, S. W. (1981). Occupational Self-Selection: A Human Capital Approach to Sex Differences in Occupational Structure. The Review of Economics and Statistics, 63(1), 60-69.

Ramirez, J. V. (2002). Age and Schooling Vintage Effects on Earnings Profiles in Switzerland. In A. De Grip \& J. Van Loo (Eds.), The Economics of Skills Obsolescence (Vol. 21, Research in Labor Economics). Amsterdam/Boston: JAI Press.

Reed, W. R., \& Dahlquist, J. (1994). Do Women Prefer Women's Work? Applied Economics, 26(12), 1133-1144l.

Rosenfeld, R. A., Trappe, H., \& Gornick, J. C. (2004). Gender and Work in Germany: Before and After the Reunification. Annual Review of Sociology, 30, 103-124.

Ruhm, C. J. (1996). The Economic Consequences of Parental Leave Mandates: Lessons from Europe (NBER Working Paper 5688). Cambridge: NBER.

Sandell, S., \& Shapiro, D. (1978). The Theory of Human Capital and the Earnings of Women: A Reexamination of the Evidence. Journal of Human Resources, 13(1), 103-177.

Skyt Nielsen, H., Simonsen, M., \& Verner, M. (2004). Does the Gap in Family-friendly Policies Drive the Family Gap? Scandinavian Journal of Economics, 106(4), 721-744.

Trappe, H., \& Rosenfeld, R.A. (2004). Occupational Sex Segregation and Family Formation in the Former East and West Germany. Work and Occupations, 31(2), 155-192.

Verbeek, M. (2004). A guide to modern econometrics (2nd [rev. and updated] ed.). Chichester [etc.]: Wiley. 
Table A-1

Frequency of occurrence and classification of ISCO codes

\begin{tabular}{|c|c|c|c|c|c|c|}
\hline ISCO & Description & $\begin{array}{c}\text { Freq. } \\
\text { all }\end{array}$ & $\begin{array}{l}\text { Freq. } \\
\text { male }\end{array}$ & $\begin{array}{l}\text { Freq. } \\
\text { fem. }\end{array}$ & $\begin{array}{c}\% \\
\text { female }\end{array}$ & Classification \\
\hline 11 & Legislators and senior officials & 19 & 19 & & 0 & male \\
\hline 111 & Legislators and senior government officials & 1 & 1 & & 0 & male \\
\hline 114 & Senior officials of special-interest organizations & 3 & 3 & & 0 & male \\
\hline 120 & Corporate managers & 15 & 9 & 6 & 40 & integ \\
\hline 121 & Directors and chief executives & 20 & 10 & 10 & 50 & integ \\
\hline 122 & Production and operations managers & 42 & 37 & 5 & 11.9 & male \\
\hline 123 & Other specialist managers & 44 & 26 & 18 & 40.9 & integ \\
\hline 130 & General managers & 5 & 1 & 4 & 80 & female \\
\hline 131 & Managers of small enterprises & 12 & 8 & 4 & 33.3 & male \\
\hline 211 & Physicists, chemists and related professionals & 6 & 4 & 2 & 33.3 & male \\
\hline 212 & Mathematicians, statisticians and related professionals & 2 & & 2 & 100 & female \\
\hline 213 & Computing professionals & 57 & 49 & 8 & 14 & male \\
\hline 214 & Architects, engineers and related professionals & 128 & 111 & 17 & 13.3 & male \\
\hline 221 & Life science professionals & 7 & 5 & 2 & 28.6 & male \\
\hline 222 & Health professionals (except nursing) & 21 & 11 & 10 & 47.6 & integ \\
\hline 231 & College, university and higher education & 11 & 7 & 4 & 36.4 & integ \\
\hline 232 & Secondary education teaching professionals & 58 & 21 & 37 & 63.8 & integ \\
\hline 233 & Primary and pre-primary education teaching professionals & 14 & & 14 & 100 & female \\
\hline 234 & Special education teaching professionals & 6 & 3 & 3 & 50 & integ \\
\hline 235 & Other teaching professionals & 12 & 5 & 7 & 58.3 & integ \\
\hline 240 & Other professionals & 3 & 3 & & 0 & male \\
\hline 241 & Business professionals & 44 & 30 & 14 & 31.8 & male \\
\hline 242 & Legal professionals & 12 & 8 & 4 & 33.3 & male \\
\hline 243 & Archivists, librarians and related information professionals & 3 & & 3 & 100 & female \\
\hline 244 & Social science and related professionals & 31 & 14 & 17 & 54.8 & integ \\
\hline 245 & Writers and creative or performing artists & 15 & 9 & 6 & 40 & integ \\
\hline 246 & Religious professionals & 3 & 2 & 1 & 33.3 & male \\
\hline 247 & Public service administrative professionals & 78 & 49 & 29 & 37.2 & integ \\
\hline 311 & Physical and engineering science technicians & 116 & 84 & 32 & 27.6 & male \\
\hline 312 & Computer associate professionals & 37 & 30 & 7 & 18.9 & male \\
\hline 313 & Optical and electronic equipment operators & 8 & 4 & 4 & 50 & integ \\
\hline 314 & Ship and aircraft controllers and technicians & 5 & 5 & & 0 & male \\
\hline 315 & Safety and quality inspectors & 14 & 13 & 1 & 7.1 & male \\
\hline 321 & Life science technicians and related associate professionals & 7 & 1 & 6 & 85.7 & female \\
\hline 322 & Health associate professionals (except nursing) & 25 & 6 & 19 & 76 & female \\
\hline 323 & Nursing and midwifery associate professionals & 89 & 19 & 70 & 78.7 & female \\
\hline 332 & Pre-primary education teaching associate professionals & 37 & 5 & 32 & 86.5 & female \\
\hline 333 & Special education teaching associate professionals & 3 & 2 & 1 & 33.3 & male \\
\hline 334 & Other teaching associate professionals & 12 & 7 & 5 & 41.7 & integ \\
\hline 341 & Finance and sales associate professionals & 145 & 67 & 78 & 53.8 & integ \\
\hline 342 & Business services agents and trade brokers & 21 & 10 & 11 & 52.4 & integ \\
\hline 343 & Administrative associate professionals & 154 & 40 & 114 & 74 & female \\
\hline 344 & Customs, tax and related government associate professionals & 69 & 22 & 47 & 68.1 & female \\
\hline 345 & Police inspectors and detectives & 27 & 22 & 5 & 18.5 & male \\
\hline 346 & Social work associate professionals & 31 & 4 & 27 & 87.1 & female \\
\hline 347 & Artistic, entertainment and sports associate professionals & 5 & & 5 & 100 & female \\
\hline 348 & Religious associate professionals & 4 & & 4 & 100 & female \\
\hline 411 & Secretaries and keyboard-operating clerks & 48 & & 48 & 100 & female \\
\hline 412 & Numerical clerks & 144 & 55 & 89 & 61.8 & integ \\
\hline
\end{tabular}


Table A-1 (continued)

Frequency of occurrence and classification of ISCO codes

\begin{tabular}{|c|c|c|c|c|c|c|}
\hline ISCO & Description & $\begin{array}{c}\text { Freq. } \\
\text { all }\end{array}$ & $\begin{array}{l}\text { Freq. } \\
\text { male }\end{array}$ & $\begin{array}{l}\text { Freq. } \\
\text { fem. }\end{array}$ & $\begin{array}{c}\% \\
\text { female }\end{array}$ & Classification \\
\hline 413 & Material-recording and transport clerks & 115 & 68 & 47 & 40.9 & integ \\
\hline 414 & Library, mail and related clerks & 16 & 8 & 8 & 50 & integ \\
\hline 419 & Other office clerks & 148 & 25 & 123 & 83.1 & female \\
\hline 421 & Cashiers, tellers and related clerks & 24 & 10 & 14 & 58.3 & integ \\
\hline 422 & Client information clerks & 31 & 4 & 27 & 87.1 & female \\
\hline 511 & Travel attendants and related workers & 3 & 2 & 1 & 33.3 & male \\
\hline 512 & Housekeeping and restaurant services workers & 56 & 16 & 40 & 71.4 & female \\
\hline 513 & Personal care and related workers & 105 & 7 & 98 & 93.3 & female \\
\hline 514 & Other personal services workers & 21 & 1 & 20 & 95.2 & female \\
\hline 516 & Protective services workers & 44 & 34 & 10 & 22.7 & male \\
\hline 522 & Shop, stall and market salespersons and demonstrators & 126 & 22 & 104 & 82.5 & female \\
\hline 610 & Market-oriented skilled agricultural and fishery workers & 2 & 1 & 1 & 50 & integ \\
\hline 611 & Market gardeners and crop growers & 17 & 4 & 13 & 76.5 & female \\
\hline 612 & Animal producers and related workers & 3 & & 3 & 100 & female \\
\hline 614 & Forestry and related workers & 2 & 2 & & 0 & male \\
\hline 711 & Miners, shotfires, stone cutters and carvers & 5 & 5 & & 0 & male \\
\hline 712 & Building frame and related trades workers & 36 & 36 & & 0 & male \\
\hline 713 & Building finishers and relateds trades workers & 90 & 88 & 2 & 2.2 & male \\
\hline 714 & Painters, building structure cleaners and related trades & 25 & 23 & 2 & 8 & male \\
\hline 721 & Metal moulders, welders, sheet-metal workers, and related & 35 & 31 & 4 & 11.4 & male \\
\hline 722 & Blacksmiths, tool-makers and related trades workers & 37 & 37 & & 0 & male \\
\hline 723 & Machinery mechanics and fitters & 100 & 96 & 4 & 4 & male \\
\hline 724 & Electrical and electronic equipment mechanics and fitters & 49 & 47 & 2 & 4.1 & male \\
\hline 731 & Precision workers in metal and related materials & 24 & 15 & 9 & 37.5 & integ \\
\hline 732 & Potters, glass-makers and related trades workers & 5 & 3 & 2 & 40 & integ \\
\hline 734 & Craft printing and related trades workers & 18 & 13 & 5 & 27.8 & male \\
\hline 741 & Food processing and related trades workers & 18 & 16 & 2 & 11.1 & male \\
\hline 742 & Wood treaters, cabinet-makers and related trades workers & 31 & 30 & 1 & 3.2 & male \\
\hline 743 & Textile, garment and related trades workers & 15 & 2 & 13 & 86.7 & female \\
\hline 744 & Pelt, leather and shoemaking trades workers & 4 & 1 & 3 & 75 & female \\
\hline 811 & Mining and mineral-processing-plant operators & 2 & 2 & & 0 & male \\
\hline 812 & Metal- processing plant operators & 5 & 5 & & 0 & male \\
\hline 814 & Wood-processing and papermaking-plant operators & 8 & 5 & 3 & 37.5 & integ \\
\hline 815 & Chemical-processing-plant operators & 25 & 22 & 3 & 12 & male \\
\hline 816 & Power-production and related plant operators & 7 & 6 & 1 & 14.3 & male \\
\hline 821 & Metal- and mineral-products machine operators & 26 & 18 & 8 & 30.8 & male \\
\hline 822 & Chemical-products machine operators & 5 & 2 & 3 & 60 & integ \\
\hline 823 & Rubber- and plastic-products machine operators & 12 & 10 & 2 & 16.7 & male \\
\hline 825 & Printing-, binding- and paper-products $\mathrm{m}$ & 2 & 2 & & 0 & male \\
\hline 826 & Textile-, fur- and leather-products machine operators & 6 & 3 & 3 & 50 & integ \\
\hline 827 & Food and related products machine operators & 7 & 5 & 2 & 28.6 & male \\
\hline 828 & Assemblers & 11 & 1 & 10 & 90.9 & female \\
\hline 829 & Other machine operators not elsewhere classified & 6 & 5 & 1 & 16.7 & male \\
\hline 831 & Locomotive engine drivers and related workers & 6 & 6 & & 0 & male \\
\hline 832 & Motor vehicle drivers & 54 & 48 & 6 & 11.1 & male \\
\hline 833 & Agricultural and other mobile plant operators & 20 & 19 & 1 & 5 & male \\
\hline 834 & Ships'deck crews and related workers & 1 & 1 & & 0 & male \\
\hline
\end{tabular}


Table A-1 (continued)

Frequency of occurrence and classification of ISCO codes

\begin{tabular}{|c|c|c|c|c|c|c|}
\hline ISCO & Description & $\begin{array}{c}\text { Freq. } \\
\text { all }\end{array}$ & $\begin{array}{c}\text { Freq. } \\
\text { male }\end{array}$ & $\begin{array}{l}\text { Freq. } \\
\text { fem. }\end{array}$ & $\begin{array}{c}\% \\
\text { female }\end{array}$ & Classification \\
\hline 913 & Domestic and related helpers, cleaners and launderers & 60 & & 60 & 100 & female \\
\hline 914 & Building caretakers, window and related cleaners & 20 & 15 & 5 & 25 & male \\
\hline 915 & Messengers, porters, doorkeepers and related workers & 8 & 4 & 4 & 50 & integ \\
\hline 916 & Garbage collectors and related labourers & 1 & 1 & & 0 & male \\
\hline 921 & Agricultural, fishery and related labourers & 5 & 3 & 2 & 40 & integ \\
\hline 931 & Mining and construction labourers & 8 & 8 & & 0 & male \\
\hline 932 & Manufacturing labourers & 41 & 16 & 25 & 60.98 & integ \\
\hline 933 & Transport labourers and freight handlers & 27 & 24 & 3 & 11.11 & male \\
\hline 991 & Unknown (GSOEP specific) & 1 & & 1 & 100 & female \\
\hline 993 & Unknown (GSOEP specific) & 1 & & 1 & 100 & female \\
\hline 997 & Unknown (GSOEP specific) & 3 & 3 & & 0 & male \\
\hline 998 & Unknown (GSOEP specific) & 17 & 9 & 8 & 47.06 & integ \\
\hline
\end{tabular}

Note: Table A-1 is made using the pooled cross-section of the four panel waves. That way, every individual appears in the sample only once. 